Justin R. Abbatemarco, MD

Mellen Center for Multiple Sclerosis,

Cleveland Clinic, Cleveland, $\mathrm{OH}$
Chen Yan, MD

Mellen Center for Multiple Sclerosis,

Cleveland Clinic, Cleveland, $\mathrm{OH}$
Amy Kunchok, MBBS

Mellen Center for Multiple Sclerosis,

Cleveland Clinic, Cleveland, $\mathrm{OH}$
Alexander Rae-Grant, MD, FAAN, FRCPC Mellen Center for Multiple Sclerosis, Cleveland Clinic, Cleveland, $\mathrm{OH}$

\title{
Antibody-mediated autoimmune encephalitis: A practical approach
}

\section{ABSTRACT}

Antibody-mediated autoimmune encephalitis (AE) is a heterogeneous group of inflammatory central nervous system disorders. Symptoms typically include subacute, progressive neuropsychiatric symptoms with associated cognitive dysfunction, movement disorders, and autoimmune seizures. The diagnosis should be based on objective neurologic dysfunction in combination with autoantibody testing. Treatment with immunotherapies requires both short-term and long-term strategies depending on the specific syndrome and potential for relapse. In this paper, we review key features of $A E$, focusing on syndromes involving cell surface and synaptic proteins, and share a practical approach to the diagnosis and management, including common pitfalls associated with nonspecific antibody findings.

\section{KEY POINTS}

$A E$ is an umbrella term for a group of inflammatory central nervous system disorders associated with neuronal autoantibodies or other biomarkers of central nervous system autoimmunity.

Common clinical presentations include progressive neurocognitive symptoms with concomitant movement disorders, seizures, and autonomic dysfunction that worsens over weeks to months.

Objective clinical findings are needed to make the diagnosis of $A E$, including changes on magnetic resonance imaging, electroencephalography, and cerebrospinal fluid analysis.
$\mathrm{T}$ HE SPECTRUM AND UNDERSTANDING OF antibody-mediated autoimmune encephalitis (AE) —an umbrella term for a group of noninfectious, inflammatory central nervous system diseases-have expanded dramatically over the past few years. Familiarity with AE syndromes ensures prompt diagnosis and treatment. Practitioners need to stay abreast of developments in this field as the breadth of immune-mediated disorders of the nervous system continues to evolve.

In this paper, we will focus on the clinical features of common central nervous system cell surface and synaptic antibody syndromes in adults and on the emerging evidence in this area that has led to rapid changes in management and treatment over the past decade. We will also briefly comment on antibody-negative AE.

Antibody-related syndromes such as intracellular neuronal antibody-associated encephalitis and encephalitis occurring with demyelinating disorders are less commonly encountered in clinical practice and are beyond the scope of this article.

\section{GENERAL FEATURES OF AUTOIMMUNE ENCEPHALITIS}

Potential associations of AE encompass paraneoplastic, parainfectious triggers along with adverse events related to various immunotherapies. ${ }^{1-3}$

Onset of AE is usually subacute over weeks to months, with progressive neurocognitive symptoms including encephalopathy, cognitive dysfunction, neuropsychiatric symptoms, and seizures. Other features may include brainstem syndromes, dysautonomia, and movement disorders. 
The prevalence and incidence are increasing as testing becomes more widely available. A recent study in Olmsted County, MN, showed a prevalence of $\mathrm{AE}$ of 13.7 per 100,000, similar to that of infectious encephalitis. ${ }^{4}$

\section{HOW IS AUTOIMMUNE ENCEPHALITIS CLASSIFIED?}

Over the past few decades, there has been rapid growth in the discovery of antibody-associated neurologic diseases. Autoantibodies that target neuronal antigens can cause a diverse set of neurologic disorders. This has significantly raised awareness of the wide spectrum of disease presentations that may have an underlying autoimmune component.

Antibodies associated with AE are commonly divided into 2 groups depending on the location of the antigen. The traditional "welldefined" syndromes (eg, anti-Hu or ANNA1, anti-Ri or ANNA-2) target intracellular neuronal antigens. ${ }^{5}$ And more recently, a new group of neuronal cell surface/synaptic proteins has been described in association with AE. This distinction is important for diagnosis and prognosis. Intracellular antibodymediated syndromes appear to be driven primarily by a CD8+ T-cell cytotoxic response and usually have a poorer prognosis, with a limited response to immunotherapy (Table 1). In contrast, cell surface/synaptic antibodies appear to be directly pathogenic and are more responsive to multimodal immunotherapies (Table 2)., ${ }^{1,5}$ Detailed discussions of the pathophysiology of AE have been published by Bradshaw and Linnoila ${ }^{6}$ and by McKeon. ${ }^{7}$

Though the terms paraneoplastic syndrome and $\mathrm{AE}$ are sometimes used interchangeably, not all AE syndromes are paraneoplastic. Paraneoplastic syndromes are defined as neurologic syndromes occurring in the setting of cancer, sometimes preceding the diagnosis of neoplasm by months or years. ${ }^{1}$ Paraneoplastic disorders are usually related to intracellular neuronal antibodies. Cell surface/synaptic antibody-mediated syndromes, however, may also be associated with cancer, though they are usually classified as phenotypes of low to moderate risk, as these disorders can occur with or without cancer. The strength of association with an underlying neoplasm varies depend- ing on the specific antibody or antibodies. ${ }^{5}$

\section{WHEN SHOULD I CONSIDER THE DIAGNOSIS?}

AE may be considered in patients presenting with subacute onset (over 1 to 3 months) of cognitive or memory deficits, alterations in consciousness, seizures, movement disorders, or other neuropsychiatric symptoms. ${ }^{8}$ Accompanying neurologic or systemic symptoms suggestive of a specific antibody-mediated syndrome can increase clinical suspicion for AE. Examples include the following:

- Dystonia-chorea for anti-N-methyl-D-aspartate (anti-NMDA) receptor encephalitis

- Hyperekplexia (exaggerated startle reflex) for anti-glycine receptor (Gly-R) antibody syndrome

- Faciobrachial dystonic seizure (focal or lateralized coordinated contractions of an arm and the face) for anti-leucine-rich glioma-inactivated protein 1 (LGI1) encephalitis

- Peripheral nerve hyperexcitability (diffuse involuntary motor-unit activity due to hyperexcitability of the motor nerve or its terminal $)^{9}$ for anti-contactin-associated protein-like 2 (Caspr2) syndrome

- Weight loss accompanying gastrointestinal symptoms for anti-dipeptidyl-peptidaselike protein 6 (DPPX) encephalitis. ${ }^{5,10}$

While certain autoantibody disorders have a specific phenotype, a number of patients with AE do not present with classic "limbic encephalitis" and can present with a range of central nervous system and peripheral nervous system involvement. ${ }^{11}$ Table 3 provides a list of potential clinical and radiographic findings suggestive of $\mathrm{AE}$.

It is also important to recognize that $\mathrm{AE}$ can be antibody-negative. Antibody-negative $\mathrm{AE}$ may occur due to limitations of currently available testing, especially as novel autoantibodies are being discovered. However, objective clinical and radiologic criteria exist to aid diagnosis. ${ }^{8}$

Despite the challenges, the diagnosis of AE should be driven by the patient's clinical presentation and diagnostic evaluation. This approach includes a detailed clinical history 


\section{TABLE 1}

\section{Autoantibody biomarkers of autoimmune encephalitis: Intracellular autoantibodies}

\begin{tabular}{|c|c|c|c|c|}
\hline A & CENTRAL NERVOL & $\begin{array}{l}\text { PERIPHERAL } \\
\text { NERVOUS SYSTEM }\end{array}$ & & ASSOCIATED \\
\hline TARG & SYSTEM FEATURES & FEATURES & OTHER & MALIGNANCY \\
\hline
\end{tabular}

High-risk paraneoplastic autoantibodies

\begin{tabular}{|c|c|c|c|c|}
\hline ANNA-1 $(\mathrm{Hu})$ & $\begin{array}{l}\text { Limbic encephalitis } \\
\text { Encephalomyelitis } \\
\text { Cerebellar ataxia }\end{array}$ & Sensory neuropathy & $\begin{array}{l}\text { Gastrointestinal } \\
\text { dysmotility }\end{array}$ & $\begin{array}{l}\text { SCLC } \\
\text { Rare: neuroblastoma }\end{array}$ \\
\hline ANNA-2 (Ri) & $\begin{array}{l}\text { Encephalomyelitis } \\
\text { Cerebellar ataxia } \\
\text { Rhombencephalitis }\end{array}$ & & $\begin{array}{l}\text { Jaw dystonia } \\
\text { Laryngospasm }\end{array}$ & $\begin{array}{l}\text { SCLC } \\
\text { Breast carcinoma }\end{array}$ \\
\hline ANNA-3 & $\begin{array}{l}\text { Limbic encephalitis } \\
\text { Encephalomyelitis } \\
\text { Cerebellar degeneration }\end{array}$ & $\begin{array}{l}\text { Sensory and sensori- } \\
\text { motor neuropathies }\end{array}$ & & SCLC \\
\hline Amphiphysin & $\begin{array}{l}\text { Stiff-person spectrum } \\
\text { disorder }\end{array}$ & & & $\begin{array}{l}\text { SCLC } \\
\text { Breast or ovarian } \\
\text { carcinoma }\end{array}$ \\
\hline CRMP-5 & $\begin{array}{l}\text { Limbic encephalitis } \\
\text { Cerebellar ataxia } \\
\text { Chorea } \\
\text { Myelopathy } \\
\text { Cranial neuropathies } \\
\text { (optic neuritis) }\end{array}$ & $\begin{array}{l}\text { Polyradiculo- } \\
\text { neuropathy }\end{array}$ & & $\begin{array}{l}\text { SCLC } \\
\text { Thymoma carcinoma }\end{array}$ \\
\hline GAD65 & $\begin{array}{l}\text { Stiff-person spectrum } \\
\text { disorder } \\
\text { Limbic encephalitis } \\
\text { Cerebellar ataxia }\end{array}$ & & & Rare \\
\hline GFAP & $\begin{array}{l}\text { Meningoencephalitis } \\
\text { Myelitis } \\
\text { Optic neuritis }\end{array}$ & & & $\begin{array}{l}\text { Ovarian teratoma } \\
\text { Adenocarcinomas } \\
\text { of various sites }\end{array}$ \\
\hline PCA-1 (Yo) & Cerebellar ataxia & & & $\begin{array}{l}\text { Breast or ovarian } \\
\text { carcinoma }\end{array}$ \\
\hline PCA-2 & $\begin{array}{l}\text { Limbic encephalitis } \\
\text { Cerebellar ataxia }\end{array}$ & Polyneuropathy & & SCLC \\
\hline PCA-Tr (DNER) & $\begin{array}{l}\text { Limbic encephalitis } \\
\text { Cerebellar ataxia }\end{array}$ & & & Hodgkin lymphoma \\
\hline $\begin{array}{l}\text { Ma } 1 \text { and } \\
\text { Ma } 2 \text { (Ta) }\end{array}$ & $\begin{array}{l}\text { Diencephalitis } \\
\text { Limbic encephalitis } \\
\text { Brain stem encephalitis } \\
\text { Cerebellar degeneration }\end{array}$ & & & $\begin{array}{l}\text { Ma1: Common, diverse } \\
\text { Ma2: Testicular semi- } \\
\text { noma }\end{array}$ \\
\hline
\end{tabular}

Negative
antibody
testing does
not rule out
autoimmune
encephalitis

ANNA = antineuronal nuclear antibody; CRMP-5 = collapsin response mediator protein 5; DNER = delta/notch-like epidermal growth factor-related receptor; GAD = glutamic acid decarboxylase; GFAP = glial fibrillary acidic protein; PCA = Purkinje cell cytoplasmic antibody; SCLC = small-cell lung cancer 


\section{TABLE 2}

\section{Autoantibody biomarkers of autoimmune encephalitis: Cell-surface and synaptic antibodies}

\begin{tabular}{|c|c|c|c|c|c|}
\hline & ANTIBODY & $\begin{array}{l}\text { CENTRAL NERVOUS } \\
\text { SYSTEM FEATURES }\end{array}$ & $\begin{array}{l}\text { PERIPHERAL } \\
\text { NERVOUS SYSTEM } \\
\text { FEATURES }\end{array}$ & $\begin{array}{l}\text { OTHER } \\
\text { FEATURES }\end{array}$ & $\begin{array}{l}\text { ASSOCIATED } \\
\text { MALIGNANCY }\end{array}$ \\
\hline & AMPAR & Limbic encephalitis & & & $\begin{array}{l}\text { SCLC } \\
\text { Breast carcinoma } \\
\text { Thymoma }\end{array}$ \\
\hline & Caspr2 & Limbic encephalitis & $\begin{array}{l}\text { Peripheral nerve } \\
\text { hyperexcitability }\end{array}$ & & $\begin{array}{l}\text { Rare, but thymoma } \\
\text { carcinoma reported }\end{array}$ \\
\hline & DPPX & $\begin{array}{l}\text { Encephalopathy } \\
\text { Myelopathy }\end{array}$ & & $\begin{array}{l}\text { GI dysmotility } \\
\text { Sleep disorder }\end{array}$ & $\begin{array}{l}\text { Rare, but lymphoma } \\
\text { reported }\end{array}$ \\
\hline & $\mathrm{D} 2 \mathrm{R}$ & $\begin{array}{l}\text { Parkinsonism } \\
\text { Encephalitis }\end{array}$ & & & \\
\hline & GABA A receptor & $\begin{array}{l}\text { Encephalitis } \\
\text { Status epilepticus }\end{array}$ & & & Thymoma \\
\hline & GABA B receptor & $\begin{array}{l}\text { Limbic encephalitis } \\
\text { Status epilepticus } \\
\text { Opsoclonus myoclonus }\end{array}$ & & & $\mathrm{SCLC}$ \\
\hline & GQ1b & $\begin{array}{l}\text { Bickerstaff brain stem } \\
\text { encephalitis }\end{array}$ & $\begin{array}{l}\text { Guillain-Barré-like } \\
\text { illness }\end{array}$ & & \\
\hline Ruling out an & IgLON5 & $\begin{array}{l}\text { Sleep disorder } \\
\text { Dementia }\end{array}$ & & $\begin{array}{l}\text { Dysphagia } \\
\text { Respiratory } \\
\text { failure }\end{array}$ & Rare \\
\hline $\begin{array}{l}\text { infectious } \\
\text { process is }\end{array}$ & LGI1 & $\begin{array}{l}\text { Limbic encephalitis } \\
\text { Faciobrachial dystonic } \\
\text { seizures }\end{array}$ & & & Thymoma \\
\hline $\begin{array}{l}\text { Important, } \\
\text { given that im- } \\
\text { munotherapies } \\
\text { can worsen }\end{array}$ & NMDA-R & $\begin{array}{l}\text { Limbic encephalitis } \\
\text { Status epilepticus } \\
\text { Movement disorders } \\
\text { Psychosis } \\
\text { Catatonia }\end{array}$ & & & Ovarian teratoma \\
\hline infection & mGluR1 & Cerebellar ataxia & & Dysgeusia & Hodgkin lymphoma \\
\hline & mGluR5 & Limbic encephalitis & & & Hodgkin lymphoma \\
\hline & Glycine receptor & $\begin{array}{l}\text { Stiff-person spectrum } \\
\text { disorder }\end{array}$ & & & Rare \\
\hline & $\begin{array}{l}\text { AMPAR }=2 \text {-amino-3-(- } \\
\text { dopamine } 2 \text { receptor; } \\
\text { leucine-rich glioma-ina } \\
\text { small cell lung cancer }\end{array}$ & $\begin{array}{l}\text { ethyl-3-oxo-1,2-oxazol-4 } \\
X=\text { dipeptidyl-peptidase } \\
\text { ated } 1 ; \text { mGluR = metabo }\end{array}$ & or; & $\begin{array}{l}\text { contactin-as } \\
\text { butyric acid; } \\
\text { anti- } N \text {-methy }\end{array}$ & $\begin{array}{l}\text { d protein-like 2; D2R = } \\
\text { astrointestinal; } L G 11= \\
\text { partate receptor; SCLC = }\end{array}$ \\
\hline
\end{tabular}

including a personal or family history of autoimmunity, identifying infectious risk factors (ie, exposure and travel history) while excluding other conditions in the differential diagnosis. ${ }^{8}$ It should also be noted that a patient with AE may not exhibit all the disease characteristics discussed below. For example, normal findings on magnetic resonance imaging (MRI) and electroencephalography (EEG) are not uncommon in anti-LGI1 encephalitis. ${ }^{12}$ 


\section{TABLE 3}

\section{Clinical, diagnostic, and radiographic clues to autoimmune encephalitis FINDINGS COMMENTS}

Subacute clinical course

Viral-like prodrome

1-3 months of symptoms

Neurocognitive deficits

Fever, malaise, headache, gastrointestinal symptoms, etc

Agitation, apathy, catatonia, delusions, irritability, mania, psychosis, and paranoia

Neurologic examination abnormalities

New-onset focal seizure disorder or status epilepticus

Ataxia, brain stem abnormalities, myoclonus, tremor, or myelopathy

New focal electroencephalogram abnormalities

Often not responsive to antiepileptic medications

Focal epileptic or slow-wave activity particularly arising from the temporal lobes

Subacute movement disorder

Dyskinesias, dystonia, or choreoathetosis

Subacute sleep disturbance

Central sleep apnea, central neurogenic hypoventilation, or narcolepsy

Subacute autonomic dysfunction

Hyperhidrosis, tachyarrhythmias, labile blood pressure, central hypoventilation, gastrointestinal dysmotility, urinary dysfunction

Brain MRI abnormalities

Bilateral T2-weighted FLAIR hyperintensities in the medial aspect of the temporal lobes, although multifocal changes involving the gray and white matter are also possible

Inflammatory cerebrospinal fluid

Mild to moderate pleocytosis (white blood cell count 5-100/uL )

Previous or current oncologic disorder or risk factors for malignancy such as smoking

Increased risk of a paraneoplastic disorder

FLAIR = fluid-attenuated inversion recovery; $\mathrm{MRI}$ = magnetic resonance imaging

\section{WHAT ARE THE COMMON CELL-SURFACE/ SYNAPTIC ANTIBODY SYNDROMES IN AUTOIMMUNE ENCEPHALITIS?}

\section{Anti-NMDA receptor encephalitis}

Anti-NMDA receptor encephalitis was initially characterized in 12 women showing a characteristic progression of psychiatric symptoms ranging from subtle behavioral changes, such as irritability, to frank psychosis. These symptoms were followed by movement disorders, autonomic dysfunction, hypoventilation, seizures, and coma. ${ }^{13}$ Anti-NMDA is one of the most frequently identified neuronal autoantibodies in AE. ${ }^{1}$ Anti-NMDA receptor encephalitis frequently affects young adults, with a strong female predominance $(4: 1)$, though it has been described in all ages including children and the elderly, with variable phenotypes. ${ }^{14}$ The median age is 20 .

Viral-like prodrome. Some patients experience a viral-like prodrome that includes headache or fever during the initial 1 to 2 weeks of the illness (Figure 1). Soon after, subacute psychiatric symptoms develop including anxiety, personality changes, hallucinations, paranoid ideas, and frank psychosis. It is not unusual for patients to alternate between hyperactive and catatonic states. Concomitant movement disorders such as dyskinesia (typically orofacial or limb), dystonia, and choreoathetosis are common. From 60\% to $75 \%$ of adult patients have been reported to experience behavioral problems or movement disorders during the first month of the disorder. ${ }^{15}$

Autonomic dysfunction. As the disease progresses, autonomic dysfunction becomes more prominent and commonly necessitates monitoring in an intensive care unit.

Potential complications include tachyarrhythmias, hypotension, and central hypoventilation requiring mechanical ventilation. Approximately $80 \%$ of patients require ICU admission. ${ }^{15}$

Seizures can occur at any time and are 


\section{NMDA receptor encephalitis: Typical clinical course}

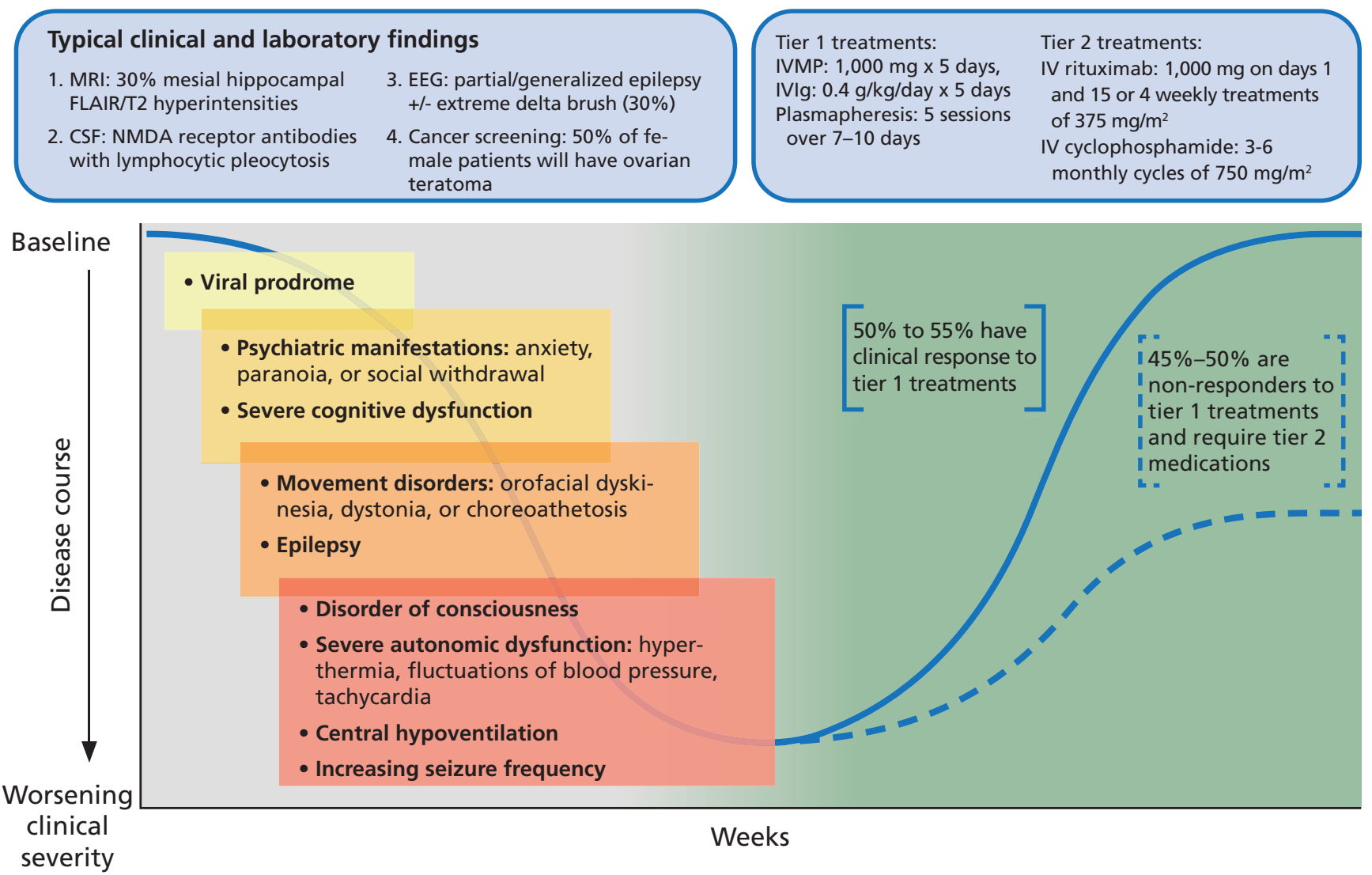

Figure 1. Typical clinical course associated with anti-NMDA receptor encephalitis.

CSF = cerebrospinal fluid; EEG = electroencephalography; FLAIR = fluid-attenuated inversion recovery; IV = intravenous; IVIg = intravenous immunoglobulin; IVMP = intravenous methylprednisolone; MRI = magnetic resonance imaging; NMDA = anti- $N$-methyl-D-aspartate receptor

often not responsive to antiepileptic medications alone. In a case series of 75 patients with anti-NMDA receptor encephalitis, almost $80 \%$ suffered from generalized tonic-clonic seizures, and $74 \%$ had focal seizures without impaired awareness. ${ }^{16}$ There has been some evidence to suggest antiepileptic drugs with sodium channel-blocking properties (eg, carbamazepine, oxcarbazepine, lacosamide, phenytoin) may be more effective, though seizure freedom is usually achieved only when paired with immunotherapies. ${ }^{16,17}$

NMDA receptor immunoglobulin G (IgG) testing should always be done with cerebrospinal fluid (CSF), as serum testing is less reliable (100\% sensitivity for CSF vs $85 \%$ for serum). ${ }^{15}$ CSF analysis usually reveals a moderate lymphocytic pleocytosis, elevated pro- tein, and intrathecal antibody production.

Patterns on EEG can vary and often simply demonstrate slowing. ${ }^{11}$ Approximately one-third of patients develop extreme delta brush; this is described as slowing with delta activity $1-3 \mathrm{~Hz}$ and superimposed bursts of rhythmic activity (beta activity $20-30 \mathrm{~Hz}$ ) on these slow waves and may be a poor prognostic sign. ${ }^{18}$

MRI findings. MRI is usually normal but may show subtle mesial hippocampal fluid-attenuated inversion recovery (FLAIR) hyperintensities. Titulaer et al reported that $76 \%$ of patients had a CSF pleocytosis, one-third of the cohort had an abnormal brain MRI, and $90 \%$ had changes on EEG including slowing. ${ }^{15}$

Teratomas. Anti-NMDA receptor encephalitis may be associated with ovarian 


\section{LGI1 encephalitis: Typical clinical course}

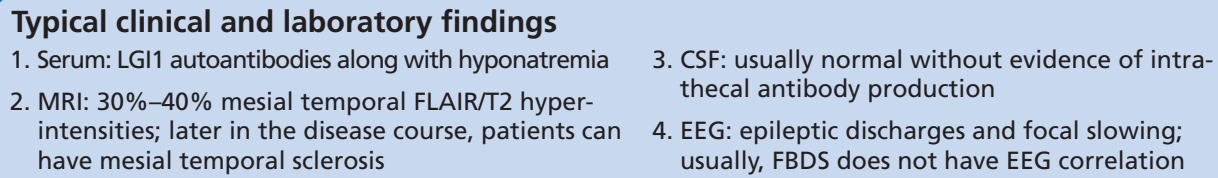

3. CSF: usually normal without evidence of intrathecal antibody production

4. EEG: epileptic discharges and focal slowing; usually, FBDS does not have EEG correlation

Tier 1 treatments: IVMP: $1,000 \mathrm{mg} \times 5$ days, IVlg: $0.4 \mathrm{~g} / \mathrm{kg} /$ day $\times 5$ days Plasmapheresis: 5 sessions over 7-10 days

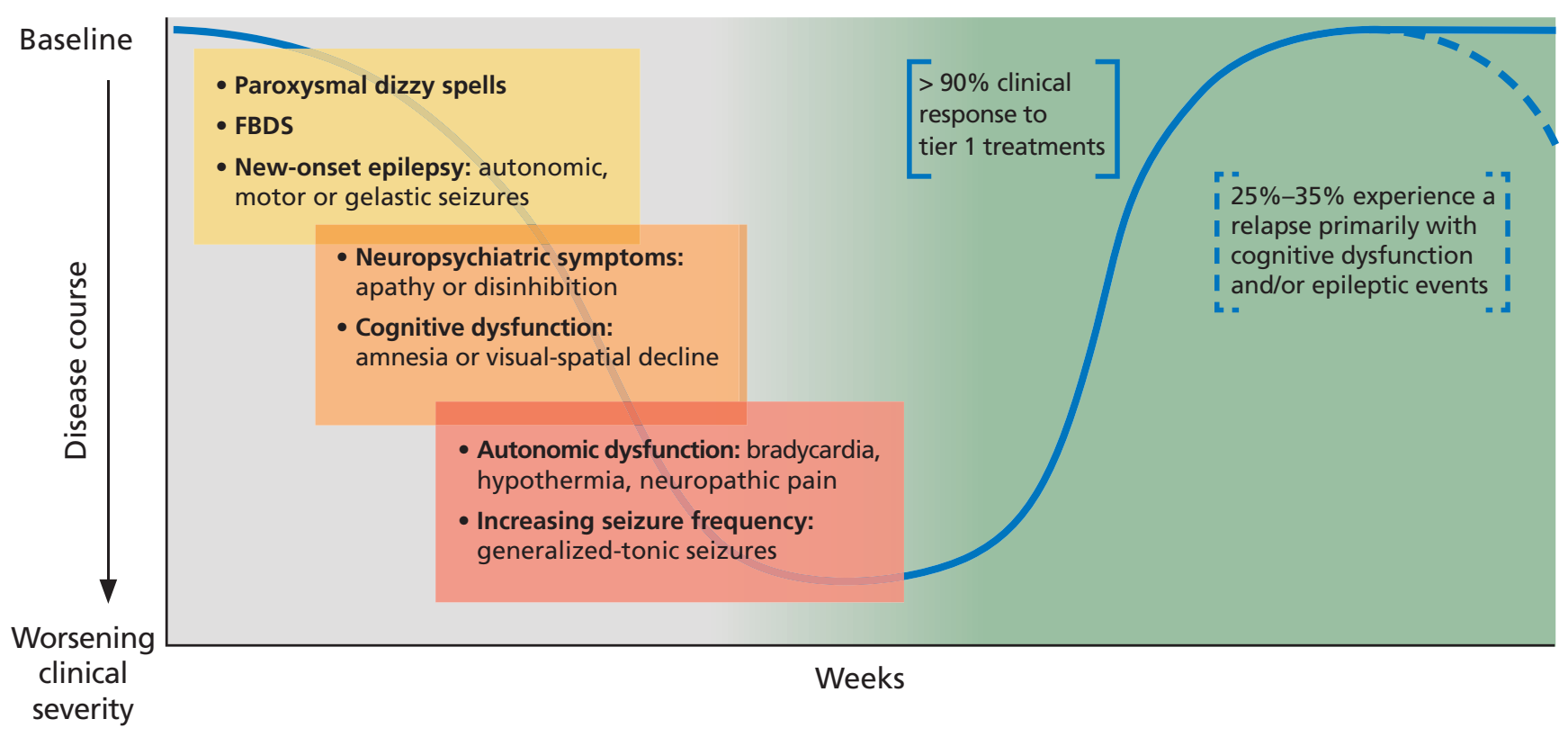

Figure 2. Typical clinical course associated with anti-LGI1 encephalitis.

CSF = cerebrospinal fluid; EEG = electroencephalography; FBDS = faciobrachial dystonic seizures; FLAIR = fluid-attenuated inversion recovery; IVIg = intravenous immunoglobulin; IVMP = intravenous methylprednisolone; $L$ GI1 = leucine-rich glioma-inactivated 1; MRI = magnetic resonance imaging

or extraovarian teratomas in $30 \%$ to $40 \%$ of patients, particularly in young women. It requires prompt surgical treatment. ${ }^{15}$

Infection. Herpes simplex virus infection of the central nervous system can also trigger the production of NMDA receptor IgG. ${ }^{19}$ In a large prospective study, $27 \%$ of patients with herpes simplex encephalitis developed antiNMDA receptor antibodies within 16 weeks of completing their acyclovir treatment. ${ }^{19}$ None of the patients had NMDA receptor IgG at the index admission. Interestingly, 3 patients $(6 \%)$ developed CSF NMDA receptor IgG without clinical correlation, but the antibody production was not detectable at 1 -year follow-up. ${ }^{19}$ There have been reports of pediatric antiNMDA receptor encephalitis developing after Japanese encephalitis infection, but no other clear postinfectious or vaccination pattern has emerged in the literature. ${ }^{20,21}$

Immunotherapy. Anti-NMDA receptor encephalitis responds to immunotherapy, but the response can be slow. In the largest study to date of patients with anti-NMDA receptor encephalitis, $81 \%$ had significant recovery at 24 months, but only $53 \%$ had clinical improvement within 4 weeks of diagnosis. ${ }^{15}$

From $10 \%$ to $25 \%$ of patients have a clinical relapse, though symptoms are less severe than in the initial presentation. . $^{1,22}$

Maintenance immunotherapy can be used to optimize acute treatment response while preventing relapses. ${ }^{15}$ Commonly used agents include oral corticosteroids, intravenous immunoglobulin (IVIg), and steroid-sparing agents such as mycophenolate mofetil, azathioprine, rituximab, and cyclophosphamide. ${ }^{23}$ 


\section{Anti-LGI1 encephalitis}

Anti-LGI1 encephalitis was first characterized in $2010 .{ }^{24}$ In contrast to anti-NMDA receptor encephalitis, it typically occurs in men over age 60 , presenting with subacute cognitive dysfunction and behavioral changes.

About $50 \%$ of patients also develop faciobrachial dystonic seizures characterized by focal or lateralized rapid coordinated movements of an arm or the face that may occur hundreds of times a day. These dystonic seizures are very specific for anti-LGI1 encephalitis but are not universally present. Most patients will have normal surface activity on EEG even if the faciobrachial seizure events are captured during the recording. The exact reason for this is unclear, but it may reflect subcortical seizure origin, as some of these patients have contralateral basal ganglia lesions on MRI. ${ }^{25}$

Other associated seizure subtypes include subtle autonomic focal seizures and generalized tonic-clonic seizures (Figure 2). ${ }^{12}$ Autonomic hyperactivity has also been reported. This includes hyperhidrosis, tachycardia, blood pressure lability, and urinary dysfunction. ${ }^{26}$

The initial workup for anti-LGI1 enceph-

Viral infections usually cause a more profound CSF pleocytosis alitis includes MRI, EEG, and CSF analysis but is usually unrevealing aside from a mild hyponatremia on basic metabolic testing. CSF-specific oligoclonal bands may be seen, but CSF can also be non-inflammatory. Initial brain MRI can occasionally demonstrate T2FLAIR hyperintensity of the hippocampus. ${ }^{27}$ Unlike in anti-NMDA receptor encephalitis, CSF is less sensitive than serum for the detection of LGI1 antibodies (serum $100 \%$ vs CSF about $88 \%) .{ }^{27,28}$

Treatment response. This syndrome characteristically responds briskly to tier 1 treatments (corticosteroids, intravenous immunoglobulin, plasmapheresis), but $20 \%$ to $30 \%$ of patients may experience a relapse necessitating long-term immunosuppression. ${ }^{22}$ In one small randomized control trial, IVIg treatment was associated with a significant reduction in seizure burden and can be considered a steroid-sparing agent. ${ }^{29}$

Malignancy. From 5\% to $15 \%$ of patients have an underlying malignancy, most commonly thymoma. ${ }^{30}$ Patients may have residual cognitive deficits despite initial recovery.

\section{WHAT TESTING SHOULD I CONSIDER FOR AE DIAGNOSIS?}

When AE is highly suspected (Table 3 ), initial testing should include an antibody panel. Both serum and CSF should be tested for antibodies since CSF is more sensitive and specific for certain antibodies such as NMDA receptor IgG, GAD65 IgG, and GFAP IgG, whereas serum is more sensitive for other antibodies such as LGI1 IgG and Caspr2 IgG.

Antibody panels are preferred over specific antibody tests, given the often overlapping clinical syndromes and the possibility of multiple positive antibodies.

Common testing sites include Mayo Clinic or Associated Regional and University $\mathrm{Pa}$ thologists (ARUP) laboratory. Antibody panels include:

- Mayo ENS-2 panel in serum (www. mayocliniclabs.com/test-catalog/Overview/92116)

- Mayo ENC-2 panel in CSF (www. mayocliniclabs.com/test-catalog/Overview/92117)

- ARUP Autoimmune Encephalitis Extended Panel in serum (https://ltd.aruplab.com/ Tests/Pub/3001431).

\section{Encephalitis has a broad differential diagnosis}

The differential diagnosis for encephalitis is very broad and includes infections, toxicmetabolic encephalopathy, mitochondrial disorders, nutritional deficiencies, vascular disorders, malignancy, and demyelinating disorders. Clinicians should be particularly concerned about ruling out an infectious process given the immunotherapies utilized to treat AE. Infections to consider include herpes simplex virus encephalitis, human herpesvirus 6, human immunodeficiency virus, fungal infection (eg, cryptococcal), mycobacterial infection, Whipple disease, and neurosyphilis.

In general, viral infections usually cause a more profound CSF pleocytosis (a white blood cell count of $50-100 / \mu \mathrm{L}$ ). Bacterial or mycobacterial infections can have a lower of CSF glucose concentration, whereas $\mathrm{AE}$ usually has normal glucose levels. ${ }^{31}$

Overall, careful examination usually reveals subtle neurologic deficits that should prompt further evaluation for AE. Diagnos- 
tic red flags include newly occurring epileptic seizures, movement disorders, and neurocognitive symptoms, especially in the setting of MRI or CSF abnormalities.

It should be mentioned that the prevalence of primary psychiatric disorders is much higher than the prevalence of AE. For example, the overall prevalence of schizophrenia, with incidence peaking in young adults, is estimated to be 2.7 to 8.3 per $1,000,32$ whereas the overall prevalence of $\mathrm{AE}$ is 13.7 per $100,000 .{ }^{4}$ Thus, in a young patient with new mood disorder, a primary psychiatric diagnosis remains more likely than AE.

While patients with a preexisting psychiatric disorder can develop a concomitant autoimmune condition, it should also be mentioned that a specific isolated psychiatric AE phenotype has not emerged in the literature despite extensive investigations. ${ }^{21}$

\section{A COMPREHENSIVE EVALUATION FOR AUTOIMMUNE ENCEPHALITIS}

A comprehensive evaluation for suspected $\mathrm{AE}$ includes a range of laboratory studies and imaging.

\section{Serum testing}

Serum testing with an AE antibody panel to human immunodeficiency virus, thyroid-stimulating hormone, vitamin deficiency $\left(B_{1}, B_{12}\right.$, E, folic acid).

\section{Evaluation for other disease markers}

Patients with autoimmune encephalitis are at increased risk of having a second autoimmune disorder. Choice of any specific testing should be based on clinical suspicion. ${ }^{7,33}$

\section{Cerebrospinal fluid testing}

CSF studies include an AE antibody panel, routine studies, CSF IgG index, CSF-specific oligoclonal bands, and comprehensive infectious evaluations with specific attention to viral agents (ie, herpes simplex virus type 1, varicella-zoster virus, West Nile virus, John Cunningham virus, and human herpesvirus $6)$.

\section{Urine toxicology screen}

A urine toxicology test should include screening for marijuana and cocaine.

\section{Magnetic resonance imaging}

MRI of the brain with and without gadolinium contrast is appropriate. Consider completing an epilepsy protocol, which may vary between institutions but usually consists of standard T1- and T2-weighted images, FLAIR, gradient-echo (T2) sequences, and diffusion-weighted sequences. Imaging sequences should also include contiguous, thin slices to ensure that hippocampal and temporal lobe lesions can be identified. ${ }^{34}$

Consider spinal cord MRI if neurologic abnormalities suggest concomitant myelitis. Symptoms could encompass motor, sensory, and autonomic (bladder, bowel, sexual) dysfunction that localizes to the spinal cord. An example could be a well-defined truncal sensory level below which the sensation is altered. ${ }^{35}$

\section{Electroencephalographic monitoring}

Continuous monitoring with EEG can clarify the cause of motor symptoms, identify suggestive patterns such as extreme delta brush, and characterize seizure burden.

\section{Positron emission tomography}

Brain fluorodeoxyglucose-positron emission tomography with computed tomography (FDG-PET/CT) may illustrate either hypometabolism that may correlate with impairment of neuronal activity even in the absence of structural disturbance ${ }^{36}$ or hypermetabolism that could correlate with increased glucose metabolism caused by synaptic dysfunction or ongoing seizure activity. ${ }^{37}$ Overall, PET may be a sensitive marker for AE but is limited by its higher cost, lack of diagnostic specificity and clinical availability. ${ }^{36}$

Body FDG-PET/CT can be done to screen for malignancy. ${ }^{38}$

\section{WHICH AUTOANTIBODY FINDINGS SHOULD BE INTERPRETED CAUTIOUSLY?}

The development of broad antibody panels has led to some unintended consequences, particularly as these panels may include disorders of the central nervous system and the peripheral nervous system. ${ }^{39}$ In addition, the specificity and sensitivity can vary for the different autoantibodies and the association with AE. Therefore, interpretation of autoantibody 
testing should be combined with a comprehensive clinical evaluation as outlined above in the section "A comprehensive evaluation for autoimmune encephalitis."

Caution is particularly needed when interpreting tests for autoantibodies that have low specificity for AE. For example, antivoltage-gated potassium channel (VGKC) antibodies were initially detected in peripheral nerve hyperexcitability disorders such as neuromyotonia and Morvan syndrome. Further laboratory evaluation has elucidated that LGI1 and Caspr2 are the usual targets of these complex antibodies and not the VGKC itself. VGKC antibodies alone are not specific for $\mathrm{AE}$ and can be seen in $5 \%$ of healthy controls. ${ }^{40}$ In VGKC-positive patients without LGI1 and Caspr2 antibodies, additional testing is not usually warranted, as there is no clear evidence that VGKC titers are indicative of an autoimmune disorder. ${ }^{30}$

Hashimoto encephalopathy, also known as steroid-responsive encephalopathy associated with autoimmune thyroiditis, has been historically linked to elevated serum levels of thyroid peroxidase antibodies. ${ }^{41}$ In the era of more neuronal-specific antibodies, thyroid peroxidase antibodies have been found to have limited diagnostic value. An extensive evaluation to exclude other causes of AE should be pursued in cases with elevated thyroid peroxidase antibody titers, given the unclear clinical significance of these antibodies in neurologic disorders. ${ }^{42,43}$

or extraovarian

teratomas

\section{WHAT IS THE INITIAL TREATMENT FOR AUTOIMMUNE ENCEPHALITIS?}

Current treatment guidelines for $\mathrm{AE}$ are based on a combination of expert opinion, case series, and case reports, and evidence from highquality multicenter randomized trials is lacking. ${ }^{29}$ But existing evidence suggests that early initiation of therapy and prompt escalation to second-line immunotherapy may lead to improved clinical outcomes. ${ }^{15,22}$

Still, unanswered questions include the time frame associated with a response to the first-line immunotherapy and the optimal duration of sustained immunotherapy. A comprehensive evaluation for malignancy is also vital as early detection and treatment are im- portant for improved patient outcomes.

An important caveat for all clinicians is that although response to corticosteroid therapy is a typical feature of $\mathrm{AE}$, it does not confirm the diagnosis of AE. Disorders such as lymphoma and vasogenic edema associated with a brain tumor can also respond dramatically to steroids. Additionally, some AE patients do not respond to corticosteroids but require prolonged treatment with other immunotherapies. ${ }^{8}$

Initiation and escalation of treatment depend on the pretest probability of AE along with the clinical severity. If there is a high pretest probability of a known syndrome, waiting for the results of antibody testing should not delay treatment. For example, a case of refractory autoimmune-mediated status epilepticus in the intensive care unit requires prompt and aggressive treatment. Caution should be used when the diagnosis is less certain. ${ }^{8}$

\section{First-line treatments}

First-line treatment for AE involves corticosteroids combined with either IVIg or plasmapheresis ${ }^{22,44}$ :

- Methylprednisolone $1 \mathrm{~g}$ daily for 5 days, followed by oral prednisone $1 \mathrm{mg} / \mathrm{kg}$ (maximum dose $60-80 \mathrm{mg}$ daily, with a prolonged taper over 3-6 months)

- IVIg $400 \mathrm{mg} / \mathrm{kg} /$ day for 5 days

- Plasmapheresis, with 5 exchanges over 7 to 8 days.

\section{Second-line treatments}

Second-line treatments can be given as monotherapy or in combination for refractory disease activity 1 to 2 weeks from completion of first-line treatment ${ }^{22}$ :

- Rituximab 1,000 mg IV, with a repeat dose in 2 weeks, or $375 \mathrm{mg} / \mathrm{m}^{2}$ weekly IV infusion for 4 weeks

- Cyclophosphamide $750 \mathrm{mg} / \mathrm{m}^{2}$ IV monthly for 3 to 6 months.

\section{Maintenance treatments ${ }^{45}$}

- Rituximab, repeat every 6 months, same dosing schedule as second-line therapy

- IVIg $0.4 \mathrm{~g} / \mathrm{kg}$ every 2 to 4 weeks

- Mycophenolate mofetil 500 to 3,000 mg/ day

- Azathioprine 1 to $3 \mathrm{mg} / \mathrm{kg} /$ day

- Cyclophosphamide 1 to $2 \mathrm{mg} / \mathrm{kg} /$ day orally. 


\section{HOW DO I MONITOR RESPONSE TO TREATMENT IN AE?}

There are no validated biological markers to assess treatment response in AE. Although some studies have suggested that early reduction in titers can correlate with better clinical outcomes, antibodies can remain positive even in patients with good outcomes. ${ }^{46}$ Further, the change in antibody titers does not consistently correlate with risk of relapse. ${ }^{47}$ Therefore, serum or CSF antibody titers in isolation are not reliable for monitoring treatment response in $\mathrm{AE}$.

Imaging, when abnormal, can be repeated to look for improvements over time. Unfortunately, even after appropriate treatment is initiated for $\mathrm{AE}$, brain MRI may show irreversible changes such as generalized or focal atrophy on follow-up.

Monitoring of the treatment response is therefore primarily based on the clinical examination. We urge clinicians to use objective measures to determine the true efficacy of a given treatment. For example, clinicians can use the Scale for the Assessment and Rating of Ataxia (SARA) ${ }^{48}$ Symbol Digit Modalities Test, or the Montreal Cognitive Assessment $(\mathrm{MoCA})^{49}$ for reliable scores to measure the success of a trial and the utility of long-term treatments. Formal neuropsychological testing is also a valuable tool to document the extent of cognitive damage and to evaluate immunotherapy response.

\section{WHAT ONCOLOGIC EVALUATION IS APPROPRIATE FOR PATIENTS WITH AE?}

Paraneoplastic AE can occur in association with an underlying malignancy. In particular, small-cell lung cancer, non-small-cell lung cancer, and neuroblastoma trigger the production of paraneoplastic autoantibodies. ${ }^{50}$ The neurologic sequelae can occur prior to detection of the cancer allowing for early discovery and oncologic treatment.

Though treating the cancer is the main goal in these patients, they may still require short-term or long-term immunotherapy for the paraneoplastic disorder. Immunotherapies that may have dual benefit to treat the cancer and autoimmune disorder, such as cyclophosphamide, can be considered.
All treatment decisions must be made in coordination with the treating oncologist. ${ }^{6}$ Additionally, patients may have permanent neurologic deficits with relatively little hope for recovery.

The type and frequency of screening for malignancy depends on the specific antibody syndrome. ${ }^{50}$ If a patient is diagnosed with an autoantibody commonly associated with paraneoplastic syndromes, frequent monitoring is recommended. In those cases, we typically order surveillance testing every 6 to 12 months for at least 3 to 5 years. If the patient has an antibody with a low likelihood of an underlying neoplasm, we consider reevaluating once a year for 3 years after the index diagnosis. ${ }^{50}$

Based on the 2011 European Federation of the Neurological Societies guidelines, we will utilize either whole-body FDG-PET or CT of the chest, abdomen, and pelvis as a screening measure for certain AE patients, with clinical consideration of the known cancer associations, cancer risk factors, or family history of cancer. $^{50}$

In particular, the nature of the antibody determines the risk and type of an underlying malignancy and therefore the investigation. For example, anti-Yo autoantibody has a greater than $90 \%$ association with breast or ovarian malignancy, so an extensive evaluation should be pursued to identify the underlying neoplasm. ${ }^{50}$

In addition, sex-specific tests such as pelvic ultrasonography, mammography, and testicular ultrasonography should be considered if the initial evaluation is unrevealing. Further, all patients should complete routine age- and sex-appropriate screening measures including screening for breast, colorectal, cervical, and prostate cancer, along with lung cancer when applicable, based on US Preventive Services Task Force recommendations.

\section{TAKE-HOME MESSAGE}

Our understanding of $\mathrm{AE}$ has expanded dramatically over the past few years. Familiarity with different $A E$ syndromes will ensure prompt diagnosis and treatment. In cases that are less clear, a sound diagnostic approach anchored on objective clinical or radiographic findings is important for optimizing outcomes. Clinicians 
need to stay abreast of developments in this field as the breadth of immune-mediated disorders of the nervous system continues to evolve.

\section{DISCLOSURES}

The authors report no relevant financial relationships which, in the context of their contributions, could be perceived as a potential conflict of interest.

\section{REFERENCES}

1. Dalmau J, Graus F. Antibody-mediated encephalitis. N Engl J Med 2018; 378(9):840-851. doi:10.1056/NEJMra1708712

2. Zekeridou A, Lennon VA. Neurologic autoimmunity in the era of checkpoint inhibitor cancer immunotherapy. Mayo Clin Proc 2019; 94(9):1865-1878. doi:10.1016/j.mayocp.2019.02.003

3. Kunchok A, Aksamit AJ Jr, Davis JM 3rd, et al. Association between tumor necrosis factor inhibitor exposure and inflammatory central nervous system events. JAMA Neurol 2020; 77(8):937-946. doi:10.1001/jamaneurol.2020.1162

4. Dubey D, Pittock SJ, Kelly CR, et al. Autoimmune encephalitis epidemiology and a comparison to infectious encephalitis. Ann Neurol 2018; 83(1):166-177. doi:10.1002/ana.25131

5. Lancaster $\mathbf{E}$. The diagnosis and treatment of autoimmune encephalitis. J Clin Neurol 2016; 12(1):1-13. doi:10.3988/jcn.2016.12.1.1

6. Bradshaw MJ, Linnoila JJ. An overview of autoimmune and paraneoplastic encephalitides. Semin Neurol 2018; 38(3):330-343. doi:10.1055/s-0038-1660821

7. McKeon A. Autoimmune encephalopathies and dementias. Continuum (Minneap Minn) 2016; 22(2 Dementia):538-558. doi:10.1212/CON.0000000000000299

8. Graus F, Titulaer MJ, Balu R, et al. A clinical approach to diagnosis of autoimmune encephalitis. Lancet Neurol 2016; 15(4):391-404. doi:10.1016/S1474-4422(15)00401-9

9. Auger RG. AAEM minimonograph \#44: diseases associated with excess motor unit activity. Muscle Nerve 1994; 17(11):1250-1263. doi:10.1002/mus.880171103

10. Dutra LA, Abrantes F, Toso FF, Pedroso JL, Barsottini OGP, Hoftberger $\mathbf{R}$. Autoimmune encephalitis: a review of diagnosis and treatment. Arq Neuropsiquiatr 2018; 76(1):41-49. doi:10.1590/0004-282X20170176

11. Ariño $H$, Armangué $T$, Petit-Pedrol $M$, et al. Anti-LGI1-associated cognitive impairment: presentation and long-term outcome. Neurology 2016; 87(8):759-765. doi:10.1212/WNL.0000000000003009

12. Bastiaansen AEM, van Sonderen A, Titulaer MJ. Autoimmune encephalitis with anti-leucine-rich glioma-inactivated 1 or anticontactin-associated protein-like 2 antibodies (formerly called voltage-gated potassium channel-complex antibodies). Curr Opin Neurol 2017; 30(3):302-309. doi:10.1097/WCO.0000000000000444

13. Dalmau J, Tüzün E, Wu HY, et al. Paraneoplastic anti-N-methyl-Daspartate receptor encephalitis associated with ovarian teratoma. Ann Neurol 2007; 61(1):25-36. doi:10.1002/ana.21050

14. Guasp M, Dalmau J. Encephalitis associated with antibodies against the NMDA receptor. Med Clin (Barc) 2018; 151(2):71-79. doi:10.1016/j.medcli.2017.10.015

15. Titulaer MJ, McCracken L, Gabilondo I, et al. Treatment and prognostic factors for long-term outcome in patients with anti-NMDA receptor encephalitis: an observational cohort study. Lancet Neurol 2013; 12(2):157-165. doi:10.1016/S1474-4422(12)70310-1

16. de Bruijn MAAM, van Sonderen A, van Coevorden-Hameete $M H$, et al. Evaluation of seizure treatment in anti-LGI1, anti-NMDAR, and anti-GABABR encephalitis. Neurology 2019; 92(19):e2185-e2196. doi:10.1212/WNL.0000000000007475

17. Feyissa AM, López Chiriboga AS, Britton JW. Antiepileptic drug therapy in patients with autoimmune epilepsy. Neurol Neuroimmunol Neuroinflamm 2017; 4(4):e353. doi:10.1212/NXI.0000000000000353

18. Schmitt SE, Pargeon K, Frechette ES, Hirsch LJ, Dalmau J, Friedman D. Extreme delta brush: a unique EEG pattern in adults with antiNMDA receptor encephalitis. Neurology 2012; 79(11):1094-1100. doi:10.1212/WNL.0b013e3182698cd8

19. Armangue T, Spatola M, Vlagea A, et al. Frequency, symptoms, risk factors, and outcomes of autoimmune encephalitis after herpes sim- plex encephalitis: a prospective observational study and retrospective analysis. Lancet Neurol 2018; 17(9):760-772. doi:10.1016/S1474-4422(18)30244-8

20. Ma J, Zhang T, Jiang L. Japanese encephalitis can trigger anti$\mathrm{N}$-methyl-D-aspartate receptor encephalitis. J Neurol 2017; 264(6):1127-1131. doi:10.1007/s00415-017-8501-4

21. Dalmau J, Armangué T, Planagumà J, et al. An update on antiNMDA receptor encephalitis for neurologists and psychiatrists: mechanisms and models. Lancet Neurol 2019; 18(11):1045-1057. doi:10.1016/S1474-4422(19)30244-3

22. Nosadini M, Mohammad SS, Ramanathan S, Brilot F, Dale RC. Immune therapy in autoimmune encephalitis: a systematic review. Expert Rev Neurother 2015; 15(12):1391-1419. doi:10.1586/14737175.2015.1115720

23. López-Chiriboga AS, Flanagan EP. Diagnostic and therapeutic approach to autoimmune neurologic disorders. Semin Neurol 2018; 38(3):392-402. doi:10.1055/s-0038-1660819

24. Irani SR, Alexander $\mathbf{S}$, Waters $\mathbf{P}$, et al. Antibodies to Kv1 potassium channel-complex proteins leucine-rich, glioma inactivated 1 protein and contactin-associated protein-2 in limbic encephalitis, Morvan's syndrome and acquired neuromyotonia. Brain 2010; 133(9):27342748. doi:10.1093/brain/awq213

25. Flanagan EP, Kotsenas AL, Britton JW, et al. Basal ganglia T1 hyperintensity in LGI1-autoantibody faciobrachial dystonic seizures. Neurol Neuroimmunol Neuroinflamm 2015; 2(6):e161. doi:10.1212/NXI.0000000000000161

26. Vernino S. Autoimmune autonomic disorders. Continuum (Minneap Minn) 2020; 26(1):44-57. doi:10.1212/CON.0000000000000812

27. van Sonderen A, Thijs RD, Coenders EC, et al. Anti-LGI1 encephalitis: clinical syndrome and long-term follow-up. Neurology 2016; 87(14):1449-1456. doi:10.1212/WNL.0000000000003173

28. Gadoth A, Pittock SJ, Dubey D, et al. Expanded phenotypes and outcomes among 256 LGI1/CASPR2-lgG-positive patients. Ann Neurol 2017; 82(1):79-92. doi:10.1002/ana.24979

29. Dubey D, Britton J, McKeon A, et al. Randomized placebo-controlled trial of intravenous immunoglobulin in autoimmune LGI1/ CASPR2 epilepsy. Ann Neurol 2020; 87(2):313-323. doi:10.1002/ana.25655

30. van Sonderen A, Schreurs MW, de Bruijn MA, et al. The relevance of VGKC positivity in the absence of LGI1 and Caspr2 antibodies. Neurology 2016; 86(18):1692-1699. doi:10.1212/WNL.0000000000002637

31. Armangue T, Leypoldt F, Dalmau J. Autoimmune encephalitis as differential diagnosis of infectious encephalitis. Curr Opin Neurol 2014; 27(3):361-368. doi:10.1097/WCO.0000000000000087

32. Messias EL, Chen CY, Eaton WW. Epidemiology of schizophrenia: review of findings and myths. Psychiatr Clin North Am 2007; 30(3):323-338. doi:10.1016/j.psc.2007.04.007

33. Galli JR, Austin SD, Greenlee JE, Clardy SL. Stiff person syndrome with Anti-GAD65 antibodies within the national veterans affairs health administration. Muscle Nerve 2018; 58(6):801-804. doi:10.1002/mus.26338

34. Bernasconi A, Cendes F, Theodore WH, et al. Recommendations for the use of structural magnetic resonance imaging in the care of patients with epilepsy: a consensus report from the International League Against Epilepsy Neuroimaging Task Force. Epilepsia 2019; 60(6):1054-1068. doi:10.1111/epi.15612

35. Frohman EM, Wingerchuk DM. Clinical practice. Transverse myelitis. N Engl J Med 2010; 363(6):564-572. doi:10.1056/NEJMcp1001112

36. Probasco JC, Solnes L, Nalluri A, et al. Abnormal brain metabolism on FDG-PET/CT is a common early finding in autoimmune encephalitis. Neurol Neuroimmunol Neuroinflamm 2017; 4(4):e352. doi:10.1212/NXI.0000000000000352

37. Leypoldt F, Buchert R, Kleiter I, et al. Fluorodeoxyglucose positron emission tomography in anti-N-methyl-D-aspartate receptor en- 
cephalitis: distinct pattern of disease. J Neurol Neurosurg Psychiatry 2012; 83(7):681-686. doi:10.1136/jnnp-2011-301969

38. McKeon A, Apiwattanakul M, Lachance DH, et al. Positron emission tomography-computed tomography in paraneoplastic neurologic disorders: systematic analysis and review. Arch Neurol 2010; 67(3):322-329. doi:10.1001/archneurol.2009.336

39. Ebright MJ, Li SH, Reynolds E, et al. Unintended consequences of Mayo paraneoplastic evaluations. Neurology 2018; 91(22):e2057e2066. doi:10.1212/WNL.0000000000006577

40. Rossi M, Mead S, Collinge J, Rudge P, Vincent A. Neuronal antibodies in patients with suspected or confirmed sporadic CreutzfeldtJakob disease. J Neurol Neurosurg Psychiatry 2015; 86(6):692-694. doi:10.1136/jnnp-2014-308695

41. Schiess N, Pardo CA. Hashimoto's encephalopathy. Ann N Y Acad Sci 2008; 1142:254-265. doi:10.1196/annals.1444.018

42. Mattozzi S, Sabater L, Escudero D, et al. Hashimoto encephalopathy in the 21st century. Neurology 2020; 94(2):e217-e224. doi:10.1212/WNL.0000000000008785

43. Valencia-Sanchez C, Pittock SJ, Mead-Harvey C, et al. Brain dysfunction and thyroid antibodies: autoimmune diagnosis and misdiagnosis. Brain Commun 2021. doi:10.1093/braincomms/fcaa233.

44. de Montmollin E, Demeret S, Brulé N, et al. Anti-N-methyl-D-aspartate receptor encephalitis in adult patients requiring intensive care. Am J Respir Crit Care Med 2017; 195(4):491-499. doi:10.1164/rccm.201603-05070C
45. Shin YW, Lee ST, Park KI, et al. Treatment strategies for autoimmune encephalitis. Ther Adv Neurol Disord 2018; 11:1-19. doi:10.1177/1756285617722347

46. Dalmau J, Gleichman AJ, Hughes EG, et al. Anti-NMDA-receptor encephalitis: case series and analysis of the effects of antibodies. Lancet Neurol 2008; 7(12):1091-1098. doi:10.1016/S1474-4422(08)70224-2

47. Irani SR, Bera K, Waters P, et al. N-methyl-D-aspartate antibody encephalitis: temporal progression of clinical and paraclinical observations in a predominantly non-paraneoplastic disorder of both sexes. Brain 2010; 133(pt 6):1655-1667. doi:10.1093/brain/awq113

48. Schmitz-Hübsch T, du Montcel ST, Baliko L, et al. Scale for the assessment and rating of ataxia: development of a new clinical scale. Neurology 2006; 66(11):1717-1720. doi:10.1212/01.wnl.0000219042.60538.92

49. Hébert J, Day GS, Steriade C, Wennberg RA, Tang-Wai DF. Longterm cognitive outcomes in patients with autoimmune encephalitis. Can J Neurol Sci 2018; 45(5):540-544. doi:10.1017/cjn.2018.33

50. Titulaer MJ, Soffietti R, Dalmau J, et al. Screening for tumours in paraneoplastic syndromes: report of an EFNS task force. Eur J Neurol 2011; 18(1):19-e3. doi:10.1111/j.1468-1331.20

Address: Justin R. Abbatemarco, MD, Mellen Center for Multiple Sclerosis, U10, Cleveland Clinic, 9500 Euclid Avenue, Cleveland, $\mathrm{OH}$ 44195; justinabbatemarco@gmail.com 